\title{
Faktor-Faktor Yang Berhubungan Dengan Peningkatan Kasus Stunting Pada Balita Di Kabupaten Probolinggo
}

\section{Zainal Munir', Kholisotin², Ayu Masrurotul Hasanah $^{3}$ \\ 1. Universitas Nurul Jadid, Email: zainalmunirnj@gmail.com \\ 2. Universitas Nurul Jadid, \\ 3. Universitas Nurul Jadid}

\section{Abstract}

Stunting is the upcoming of indeks condition in the higher level that is based on the age. minus and standar devision according to WHO. Stunting is manifestation with no limition factor of the diet consumer. Who has low quality and also the protein in the growing up development it is started since first life. Planing observation to find factor relation between the case of stunting development since baby in probolinggo regency. This quantitative observation to close sectional cross with sampel election by using random sampling those are 52 respodens. Based on analyze of data that is used by univariat analisa, bivariat usage based on chi square uji. As the result of this observation those are : (1) the relation of mother protein with the improvementof stunting case for the baby with $p$ value $0,003<0,05$. (2) the relation of upbringing of stunting case for baby in $p$ value : $0,002<0,05$. (3) the relation of economic factor in upbringing stuntinnf case for baby with $p$ value 0,004<0,05 in summary : bored on the relation between variable and stunting case of baby, government observation in society in 
the healthy instansi job to obigate and practice based of the schedule which given in every groups. This about the importance of protecting dtunting from now. and also it can be more spesific for mother in protecting stunting from now and give more protein for the son to make e qucil.

Keywords: Mother protein when she is pragnant, pattern, economic factor

\section{Abstrak}

Stunting merupakan keadaan indeks tinggi badan menurut umur di bawah minus dua standar deviasi berdasarkan WHO. Stunting merupakan manifestasi jangka panjang faktor konsumsi diet berkualitas rendah atau kurang gizi kronik, pada masa pertumbuhan dan perkembangan sejak awal kehidupan. Tujuan penelitian ini adalah untuk mengetahui faktor-faktor yang berhubungan dengan peningkatan kasus stunting pada balita di kabupaten probolinggo. Penelitian ini merupakan penelitian kuantitatif dengan pendekatan cross sectional dengan pemilihan sampel menggunakan random sampling sebanyak 52 responden. Analisis data yang di gunakan adalah analisa univariat, bivariat menggunakan uji chi square. Hasil penelitian ini (1) terdapat hubungan antara gizi ibu saat hamil dengan peningkatan kasus stunting pada balita denganp $\mathrm{p}$ value $0,003<0,05(2)$ terdapat hubungan antara pola asuh dengan peningkatan kasus stuntingi pada balita denganp $\mathrm{p}$ value 0,002 $<0,05$ (3) terdapat hubungan antara faktor 
ekonomi dengan peningkatan kasus stuntingi pada balita dengan $\mathrm{p}$ value 0,004 $<0,05$, kesimpulan: terdapat hubungan dari masing-masing variable terhadap peningkatan kasus stunting pada balita saran: penelitian ini menyarankan pemerintah, pada petugas instansi kesehatan agar dapat memberikan penyuluhan di berikan secara terjadwal dan dalam kelompok, tentang pentingnya pencegahan stunting sejak dini, dan dapat memberikan pelayanan lebih optimal pada balita yang berisiko terjadinya stunting, serta memberikan asupan nutrien yang seimbang

Kata Kunci: Gizi ibu pada saat hamil, pola asuh, faktor ekonomi 


\section{Pendahuluan}

Stunting atau yang di sebut pendek di gambarkan sebagai seorang balita yang memiliki tinggi badan lebih rendah dari standart tinggi badan balita seumurannya (Maryati dewi, mimin Aminah, 2016). Stunting merupakan suatu gambaran dari status gizi kurang yang bersifat kronik atau menahun pada masa pertumbuhan dan perkembangan sejak awal kehidupan yaitu dari mulai ibu hamil sampai anak di lahirkan (Khoirun Ni'mah, Siti Rahayu Nadhiroh, 2015).

Masa anak di bawah lima tahun atau yang sering di sebut balita merupakan periode penting dalam tumbuh kembang balita karena pertumbuhan dan perkembangan dasar yang berlangsung pada masa balita akan memengaruhi dan menentukan setiap perkembangan yang selanjutnya. balita adalah anak yang telah menginjak usia diatas 1 tahun atau lebih terkenalnya usia anak di bawah 5 tahun. Pada usia balita pertumbuhan anak sangat pesat sehingga memerlukan pola asuh orang tua (Vicka Lourine Rapar, Sefti Rompas, Amatus Yudi Ismanto, 2014).

Gizi ibu sebelum dan selama kehamilan merupakan penyebab yang memberikan kontribusi terhadap pertumbuhan dan perkembangan janin. Ibu hamil dengan gizi kurang. karena pendapatan yang rendah terhadap ketidak mampuan untuk mendapatkan pangan yang kucup dan berkualitas karena rendahnya daya beli akan memberikan dampak buruk terhadap anak dan mengakibatkan BBLR atau berat badan lahir rendah pada anaknya (Rizki Kurnia Illahi, 2017). Pola asuh dalam pemberian makanan merupakan kemampuan orang tua dan keluarga untuk menyediakan waktu, perhatian dan dukungan dalam memberikan makanan kepada anaknya. Karena pola asuh pemberian makanan yang tidak kreatif dan variatif 
sangatlah perlu di perhatikan ibu a gar kebutuhan gizi anaknya terpenuhi (Risani Rambu Podu Loya, Nuryanto, 2017).

Sosial ekonomi keluarga merupakan salah satu faktor yang menentukan jumlah makanan yang tersedia dalam keluarga sehingga turut menentukan status gizi keluarga tersebut dan juga termasuk ikut mempengaruhi

pertumbuhan pada anak (Ibrahim, dkk, 2019). Tingginya angka pernikahan dini di indonesia menyebabkan kehamilan pertama juga terjadi di usia dini atau saat ibu masih remaja biasanya sering di sebut kehamilan remaja. Usia ibu ketika pertama kali hamil sangat berpengaruh terhadap jalannya kehamilan . usia ideal wanita untuk melahirkan adalah 20-25 tahun. Jika usia ibu lebih mudah atau lebih tua dari usia tersebut maka akan beresiko mengalami komplikasi kehamilan. seorang wanita yang hamil pada usia remaaja akan mendapatkan early prenatal care lebih sedikit. Faktor ini di prediksikan menyebabkan BBLR serta kematian pada bayi. Kematian bayi, bayi premature dan bayi lahir dengan berat badan rendah akan tingii pada pasangan remaja, usia laki-laki dan perempuan sama berpengaruhnya terhadap ha 1 ini (Dwi Agista Larasati, Triska Susila Nindya, Yuni Sufyanti Arief, 2018).

Pendidikan ibu yang rendah merupakan faktor resiko yang penting pada pertumbuhan anaknya, peranan ibu sebagai pengasuh utama anaknya sangat di perlukan mulai dari pembelian hingga penyajian makanan. Jika pendidikan dan pengetahuan ibu rendah akibatnya ia tidak akan mampu memilih hingga menyajikan makanan yang memenuhi syarat gizi seimbang (Atikah Rahayu, dan Laily Khairiyati, 2014). Jumlah anggota keluarga juga berpengaruh pada faktor terjadinya stunting pada balita. Hal ini di sebabkan memiliki banyak anak terutama dengan kondisi ekonomi 
kurang tidak akan memberikan perhatian dan makanan ya ng cukup pada seluruh anakanaknya seperti kebutuhan primer yaitu sandang, pangan dan papan (Dian Febrida Sari, Reski Oktacia,2018).

Berat badan lahir rendah adalah faktor yang paling dominan terhadap kejadian stunting, BBLR merupakan salah satu indikator gagal tumbuh yang dapat menyiratkan potensi fisik dan emosional. gizi merupakan permasalahan yang paling erat kaitannya dengan proses pertumbuhan dan perkembangan balita . balita merupakan suatu periode pertumbuhan dan perkembangan yang cukup pesat sehingga pada masa ini penjagaan pemenuhan gizi harus adekuat agar tahapan pertumbuhan dan perkembangannya optimal (Siti Syofiatul Rohmah, Suyatno, Martha Irene Kartasurya, 2018).

Pengetahuan ibu yang rendah merupakan faktor resiko yang penting pada

anak.ibu pertumbuhan pengetahuan dengan berisiko 5,1 kali lebih besar memiliki anak stunting. Pengetahuan ibu mempunyai peranan penting dalam kejadian stunting pada balita (Atikah Rahayu,Laily Khairiyati, 2016)

\section{Metode}

Jenis penelitian penelitian survey analitik dengan desain crosssectional. Analisa menggunakan Univariat dan bivariate dengan menggunakan uji chi square, nilai $\mathrm{p} \leq 0,05$ berarti hasil perhitungan statistik bermakna (signifikan) atau menunjukkan ada hubungan antara variabel independen dengan variabel dependen.

\section{Hasil Penelitian}

1. Distribusi Gizi Ibu Pada Saat Hamil Pada Responden Stunting di Kabupaten Probolinggo. Tabel 1: Distribusi Gizi Ibu Pada Saat Hamil

\begin{tabular}{c|c|c} 
Karakteristik & F & (\%) \\
\hline $\begin{array}{c}\text { Gizi ibu pada saat } \\
\text { hamil }\end{array}$ & & \\
\hline Baik & 10 & $19,2 \%$ \\
\hline Cukup & 18 & $34,6 \%$ \\
\hline Kurang & 24 & $46,2 \%$ \\
\hline Total & $\mathbf{5 2}$ & $\mathbf{1 0 0} \%$
\end{tabular}

Sumber: Angket Penelitian 


\section{Zainal Munir: Stunting Balita}

Dari tabel 1 diatas didapatkan hasil bahwa gizi ibu pada saat hamil pada responden Stunting di Kabupaten Probolinggo mayoritas mengalami gizi kurang yaitu 24 responden $(46,2 \%)$.

2. Distribusi Pola Asuh pada responden Stunting di Kabupaten Probolinggo Tabel 2 Distribusi Pola Asuh

\begin{tabular}{c|c|c} 
Karakteristik & F & $\mathbf{( \% )}$ \\
\hline Pola Asuh & & \\
\hline Baik & 19 & $36,5 \%$ \\
\hline Buruk & 33 & $63,5 \%$ \\
\hline Total & 52 & $100 \%$
\end{tabular}

Sumber: Angket Penelitian Dari tabel 2 diatas menunjukkan bahwa Pola Asuh pada responden Stunting di Kabupaten Probolinggo mayoritas Buruk yaitu 33 (63,5\%) responden

3. Distribusi

faktor

ekonomi pada responden Stunting di Kabupaten Probolinggo Tabel 3 Distribusi ekonomi

\begin{tabular}{c|c|c} 
Karakteristik & F & (\%) \\
\hline Faktor Ekonomi & & \\
\hline Rendah & 32 & $58,2 \%$ \\
\hline Cukup & 14 & $25,5 \%$ \\
\hline Baik & 6 & $10,9 \%$ \\
\hline Total & $\mathbf{5 2}$ & $\mathbf{1 0 0} \%$
\end{tabular}

Sumber: Angket Penelitian

Dari tabel 3 diatas menunjukkan bahwa Faktor Ekonomi pada responden Stunting di Kabupaten Probolinggo mayoritas rendah yaitu 32 Responden $(58,2 \%)$ dari 52 responden

4. Distribusi Hubungan Gizi ibu pada saat hamil dengan Peningkatan kasus Stunting pada balita di Kabupaten Probolinggo

Tabel 4 Distribusi gizi ibu pada saat hamil dengan peningkatan kasus stunting pada balita di kabupaten probolinggo

\begin{tabular}{c|c|c|c|c|c|c|c}
\multirow{2}{*}{$\begin{array}{c}\text { Gizi ibu } \\
\text { pada saat } \\
\text { hamil }\end{array}$} & \multicolumn{4}{|c|}{ Peningkatan } & \multicolumn{2}{|c|}{ Sendek } & \multicolumn{2}{|c|}{$\begin{array}{c}\text { Sangat } \\
\text { pendek }\end{array}$} & \multicolumn{2}{|c}{ Jumlah } & \multirow{2}{*}{ P Value } \\
\cline { 2 - 7 } & F & $\%$ & F & $\%$ & F & $\%$ & \\
\hline Baik & - & - & - & - & - & - & \multirow{2}{*}{0,003} \\
\hline Cukup & 2 & 4,0 & 5 & 10,5 & 7 & 14 & \\
& & & & & &, 5 & \\
\hline Kurang & 19 & 36,1 & 26 & 49,4 & 45 & 85 & \\
Baik & & & & & &, 5 & \\
\hline Total & 21 & 40,1 & 31 & 59,9 & 52 & 10 & \\
& & & & & & 0 &
\end{tabular}

Sumber : Angket Penelitian

Dari tabel 4 diatas menunjukkan bahwa Hubungan gizi ibu pada saat hamil dengan peningkatan kasus stunting pada balita menunjukkan bahwa responden sebanyak 52 responden. Didapatkan hasil bahwa sebagian besar responden dengan peningkatan kasus stunting 
pada balita dengan kategori sangat pendek sebanyak 31 $(59,9 \%)$ responden. Hasil uji statistic chi- square didapatkan bahwa nilai $\mathrm{P}$ value 0,003 . Karena nilai $\mathrm{P}<$ 0,05 maka hipotesis $\mathrm{Ha}$ diterima dan Ho ditolak sehingga dapat disimpulkan bahwa ada hubungan yang signifikan antara gizi ibu pada saat hamil dengan peningkatan kasus stunting pada balita di kabupaten probolinggo.

\section{Distribusi Hubungan} Pola Asuh dengan Peningkatan kasus Stunting pada balita di Kabupaten Probolinggo Tabel 5 Distribusi Pola Asuh dengan peningkatan kasus stunting pada balita di kabupaten probolinnggo

\begin{tabular}{|c|c|c|c|c|c|c|c|}
\hline \multirow{3}{*}{ Pola Asuh } & \multicolumn{4}{|c|}{ Kasus stunting } & \multirow{2}{*}{\multicolumn{2}{|c|}{ Jumlah }} & \multirow{3}{*}{$\begin{array}{c}\mathbf{P} \\
\text { Value }\end{array}$} \\
\hline & \multicolumn{2}{|c|}{ Pendek } & \multicolumn{2}{|c|}{$\begin{array}{l}\text { Sangat } \\
\text { pendek }\end{array}$} & & & \\
\hline & $\mathbf{F}$ & $\%$ & $\mathbf{F}$ & $\%$ & $\mathbf{F}$ & $\%$ & \\
\hline Baik & - & - & - & - & - & - & 0,002 \\
\hline Cukup & 1 & 2,0 & 5 & 10,0 & 7 & 12,0 & \\
\hline Kurang Baik & 20 & 40,0 & 26 & 48,0 & 45 & 88,0 & \\
\hline Total & 21 & 42,0 & 31 & 58,0 & 52 & 100 & \\
\hline
\end{tabular}

Sumber : Angket Penelitian

$\begin{array}{llr}\text { Dari tabel } 5 & \text { diatas } \\ \text { menunjukkan } & \text { bahwa } \\ \text { Hubungan }\end{array}$ dengan Peningkatan kasus Stunting pada balita di Kabupaten Probolinggo menunjukkan bahwa responden sebanyak 52 responden. Didapatkan hasil bahwa sebagian besar responden dengan pola asuh kurang baik dengan kategori sangat pendek sebanyak 31 $(58,0 \%)$ responden. Hasil uji statistic chi- square didapatkan bahwa nilai $\mathrm{P}$ value 0,002 . Karena nilai $P$ $<0,05$ maka hipotesis Ha diterima dan Ho ditolak sehingga dapat disimpulkan bahwa ada hubungan yang signifikan antara pola asuh dengan peningkatan kasus stunting pada balita di kabupaten probolinggo.

6. Distribusi Hubungan Faktor Ekonomi dengan Peningkatan kasus Stunting pada balita di kabupaten probolinggo

Tabel 6 Distribusi Faktor Ekonomi dengan peningkatan kasus stunting pada balita di kabupaten probolinnggo

\begin{tabular}{|c|c|c|c|c|c|c|c|}
\hline \multirow{3}{*}{$\begin{array}{l}\text { Faktor } \\
\text { Ekono } \\
\text { mi }\end{array}$} & \multicolumn{4}{|c|}{ Kasus stunting } & \multirow{2}{*}{\multicolumn{2}{|c|}{ Jumlah }} & \multirow{3}{*}{$\begin{array}{c}\mathbf{P} \\
\text { Value }\end{array}$} \\
\hline & \multicolumn{2}{|c|}{ Pendek } & \multicolumn{2}{|c|}{$\begin{array}{l}\text { Sangat } \\
\text { pendek }\end{array}$} & & & \\
\hline & $\mathbf{F}$ & $\%$ & $\mathbf{F}$ & $\%$ & $\mathbf{F}$ & $\%$ & \\
\hline Tinggi & 1 & 2,0 & 2 & 4,9 & & & \multirow{2}{*}{0,004} \\
\hline Cukup & $\begin{array}{l}1 \\
3\end{array}$ & $\begin{array}{c}24, \\
7\end{array}$ & $\begin{array}{l}1 \\
8\end{array}$ & $\begin{array}{c}34, \\
2\end{array}$ & 7 & $\begin{array}{c}12, \\
0\end{array}$ & \\
\hline $\begin{array}{l}\text { Renda } \\
\mathrm{h}\end{array}$ & 7 & $\begin{array}{c}13, \\
3\end{array}$ & $\begin{array}{l}1 \\
1\end{array}$ & $\begin{array}{c}20 \\
9\end{array}$ & $\begin{array}{l}4 \\
5\end{array}$ & $\begin{array}{c}88, \\
0\end{array}$ & \\
\hline Total & $\begin{array}{l}2 \\
1\end{array}$ & $\begin{array}{c}40, \\
0\end{array}$ & $\begin{array}{l}3 \\
1\end{array}$ & $\begin{array}{c}60 \\
0\end{array}$ & $\begin{array}{l}5 \\
2\end{array}$ & $\begin{array}{c}10 \\
0\end{array}$ & \\
\hline
\end{tabular}

Sumber: Angket Penelitian 


\begin{abstract}
Dari tabel 6 diatas menunjukkan bahwa tabulasi silang Hubungan Faktor Ekonomi dengan Peningkatan kasus Stunting pada balita di Kabupaten Probolinggo menunjukkan bahwa responden sebanyak 52 responden. Didapatkan hasil bahwa sebagian besar responden dengan Faktor Ekonomi cukup dengan katagori sangat pendek sebanyak 31 $(60,0 \%)$ responden . Hasil uji statistic chi- square didapatkan bahwa nilai $\mathrm{p}$ value 0,004 . Karena nilai $P$ $<$ 0,05 maka hipotesis Ha diterima dan Ho ditolak sehingga dapat disimpulkan bahwa ada hubungan yang signifikan antara pola asuh dengan peningkatan kasus stunting pada balita di kabupaten probolinggo.
\end{abstract}

\section{Pembahasan}

\section{a. Hubungan gizi ibu pada saat hamil dengan peningkatan kasus stunting pada balita}

Berdasarkan Hasil penelitian di Kabupaten Probolinggo mengenai hubungan gizi ibu pada saat hamil dengan peningkatan kasus stunting pada balita berdasarkan tabel 3 sebagian besar responden peningkatan kasus stunting pada balita yang gizi ibu pada saat hamil yaitu kurang baik sebanyak 19 orang $(36,1 \%)$ dengan peningkatan kasus stunting pada balita de ngan katagori pendek, sedangkan peningkatan kasus stunting pada balita dengan katagori sangat pendek sebanyak 26 orang $(49,4 \%)$. Hasil analisis stunting pada penelitian ini adalah pada gizi ibu saat hamil dengan katagori sangat pendek dengan peningkatan kasus Stunting pada balita yaitu sebanyak 26 orang $(49,4 \%)$ untuk masingmasing kategori.

Hasil analisis Uji chisquare pada table 3 di peroleh $p$-value dengan hasil 0,003<0,05 maka dapat di simpulkan bahwa ada hubungan antara gizi ibu pada saat hamil dengan peningkatan kasus stunting pada balitta di kabupaten probolinggo.

$\mathrm{Hal}$ tersebut sependapat dengan 
penelitian oleh sukmawati dkk dalam penelitianya hasil uji statistic di peroleh nilai $p=0,01 \quad(<0.05)$ yang berarti ada hubungan yang signifikan antara gizi ibu pada saat hamil dengan kejadian stunting. Kehamilan menyebabkan meningkatnya metabolisme energi karena itu kebutuhan energi dan zat gizi lainnya meningkat selama kehamilan. peningkatan energi dan zat gizi tersebut di perlukan untuk pertumbuhan dan perkembangan janin, pertambahan besarnya organ kandungan , perubahan komposisi dan metabolisme tubuh ibu, sehingga kekurangan zat gizi tertentu yang di per lukan saat hamil akan menyebabkan stunting (Sukmawati, Hendrayati,

Chaerunnimah, $\&$ Nurhumaira. 2018).

Ibu hamil perlu menjaga makanmakanan yang di konsumsi yang di butuhkan oleh tubuh agar gizi ibu saat hamil terpenuhi. Gizi ibu yang baik dengan makanmakanan yang kaya protein, lemak, kalsium, kalori seperti tempe, tahu, ikan, telur sayur dan buah2an dan kacang-kacangan, ibu yang berstatus gizi kurang akan beresiko mengalami kelahiran bayi stunting karena gizi ibu selama kehamilan dapat di manifestasikan sebagai keadaan tubuh akibat dari pemakaian, penyerapan dan penggunaan makanan yang dapat mempengaruhi

pertumbuhan dan perkembangan janin. Gizi ibu saat hamil sangat penting untuk pertumbuhan janin yang di kandungnya . pada umumnya, ibu hamil dengan kondisi kesehtana yang baik yang tidak ada gangguan gizi pada saat hamil , akan menghasilkan bayi yang lebih sehat dari pada ibu hamil yang kondisinya memiliki gangguan gizi. Kurangnya energi kronis akan menyebabkan lahirnya anak dengan 
bentuk tubuh "stunting" (Alfarisi, R., Nurmalasari, Y., \& Nabila, S., 2019).

Menurut peneliti Gizi ibu pada saat hamil sangat mempengaruhi pertumbuhan janin dalam kandungan apabila gizi ibu pada saat hamil buruk/ kurang maka akan mengakibatkan

terhambatnya

pertumbuhan

pada

janin dan beresiko melahirkan balita stunting.

Karena percepatan perbaikan gizi pada 1000 hari pertama kehidupan, periode seribu hari ini maksudnya yaitu 270 hari selama kehamilan dan 730 hari pada kehidupan pertama bayi merupakan periode sensitif karena dampak yang di timbulkan terhadap bayi pada masa ini akan bersifat permanen dan tidak dapat di koreksi atau di sebut kegagalan pertumbuhan (stunting).

Kekurang gizi yang terjadi pada saat hamil dan awal kehidupan menyebabkan janin melakukan reaksi penyesuaian . secara pararel penyesuaian tersebut meliputi perlambatan pertumbuhan dengan pengurangan jumlah dan pengembangan selsel tubuh termasuk sel otak dan organ tubuh lainnya.hasil reaksi penyesuaian akibat kekurangan gizi di ekspedisi pada usia dewasa dalam bentuk tubuh yang pendek, rendahnya kemampuan kognitif atau kecerdasan sabagai akibat tidak optimalnya

pertumbuhan dan perkembangan yang di sebabkan oleh kurangnya gizi pada balita di dalam kandungan

b. Hubungan pola asuh dengan peningkatan kasus stunting pada balita

Berdasarkan hasil penelitian di Kabupaten Probolinggo mengenai pola asuh dengan peningkatan kasus stunting pada balita berdasarkan tabel 4 sebagian besar responden peningkatan kasus stunting pada balita berPola Asuh 
kurang baik sebanyak 26 orang $(48,0 \%)$ responden dengan peningkatan kasus stunting pada balita. Hasil uji chi-square pada tabel 4 di dapatkan bahwa nilai P-value sebesar $\quad 0,002>0,05$ maka Ha di terima dan Ho di tolak sehingga dapat di simpulkan bahwa terdapat hubungan antara pola asuh dengan peningkatan kasus stunting pada balita di kabupaten probolinggo. Pola asuh orang tua salah satu aspek kunci dalam pola asuh gizi meliputi pemberian makanan. Oleh karena itu pola asuh dalam pemberian makanan sangat penting bagi anak, karena orang tua berperan penting bagi pemenuhan gizi, sehingga jika orang tua yang kurang memperhatikan anaknya dalam hal pemberian makan akan terjadi masalah status gizi. Pola asuh yang baik akan mempunyai status gizi anak yang normal, sebaliknya jika pola asuh kurang baik akan mempengaruhi status gizi pada anak dan akan mengakibatkan stunting (Yudianti, R. H. S., 2016) Pola asuh memiliki peran dalam kejadian stunting pada balita karena asupan makanan pada balita sepenuhnya diatur oleh ibunya. Ibu dengan pola asuh baik akan cenderung memiliki balita dengan status gizi yang lebih baik dari pada ibu dengan pola asuh yang kurang baik. Pola asuh merupakan faktor yang berhubungan dengan status gizi anak termasuk stunting pola asuh memiliki peranan penting dalam pertumbuhan anak yang optimal. kualitas dan kuantitas asupan gizi pada makanan anak perlu mendapat perhatian, hal ini diperlukan karena makanan yang di berikan ibu kepada anaknya sering rendah akan zat gizi yang di butuhkan untuk menunjang pertumbuhan agar gizi anak terpenuhi (Kullu, 
venny marisai, Yasnani, \& Lestari, H, 2019).

Menurut peneliti pola asuh yang baik pada anak akan memberikan hasil yang baik terhadap perkembangan fisik , mental dan sosial anak, pola asuh yang kurang pada balita dapat menyebabkan stunting 3,6 kali lebih besar di bandingkan dengan yang memiliki pola asuh yang baik

c. Hubungan ekonomi faktor peningkatan kasus stunting pada balita

Hasil penelitian di Kabupaten Probolinggo mengenai hubungan Faktor Ekonomi dengan peningkatan kasus stunting pada balita berdasarkan tabel 5 menjelaskan tabulasi silang Hubungan Faktor ekonomi dengan peningkatan kasus stunting pada balita menunjukkan bahwa dari responden sebanyak 52 responden, didapatkan hasil sebagian besar responden dengan faktor ekonomi cukup dalam kategori sangat pendek sebanyak 18 orang $(34,2 \quad \%)$ responden. dengan peningkatan kasus stunting pada balita .

Hasil uji chi- square pada tabel 5.9 didapatkan bahwa nilai $\mathrm{P}$-value $\quad 0,021>0,05$ maka Ho diterima dan Ha ditolak sehingga dapat disimpulkan bahwa terdapat hubungan antara faktor ekonomi dengan peningkatan kasus stunting pada balita di kabupaten probolinggo.

Penelitian ini sependapat dengan penelitian sebelumnya yang mengatakan bahwa anak balita yang mengalami stunting sebesar $41,7 \%$ karean pendapatan keluarga yang rendah sedangkan proporsi anak balitayang keadaan gizinya normal sebesar $81,2 \%$ yaitu pada kelurag yang berpendapatan tinggi. Hasil uji statistik di peroleh nilai $\mathrm{p}=0,026$ $(\mathrm{p}<0,05)$ sehingga Ho di tolak dan Ha di terima, hal ini bahwa kejadian stunting pada anak balita di sebabkan oleh 


\begin{tabular}{|c|c|}
\hline \multirow{2}{*}{\multicolumn{2}{|c|}{$\begin{array}{lr}\text { pendapatan } & \text { keluarga } \\
\text { yang rendah, } & \text { artinya } \\
\text { anak balita } & \text { yang } \\
\text { mengalami } & \text { stunting } \\
\text { resikonya } 3 \text { kali lebih }\end{array}$}} \\
\hline & \\
\hline besar di sebabkan oleh & faktor ekonomi yang \\
\hline 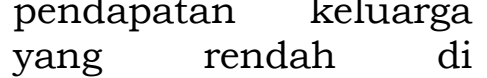 & $\begin{array}{l}\text { rendah } \\
\text { mempengaruhi kualitas }\end{array}$ \\
\hline bandingkan dengan & dan kuantitas bahan \\
\hline eluarga & makanan yang \\
\hline erpendapatan & konsumsi oleh keluarga \\
\hline ondisi sosial ekonomi & . makanan yang di dapat \\
\hline ada masyarakat miskin & biasanya akan kurang \\
\hline lenyebabkan tingginya & bevariasi dan sedikit \\
\hline masalah gizi & jumlahnya terutama \\
\hline terjadi, $\quad$ hal ini & pada bahan sumber \\
\hline $\begin{array}{l}\text { merupakan akibat dari } \\
\text { sulitnya akses pangan }\end{array}$ & $\begin{array}{lr}\text { protein, } & \text { vitamin dan } \\
\text { mineral. } & \text { Semakin }\end{array}$ \\
\hline lan akses terhadap & meningkatnya \\
\hline elayanan kesehatan . & ekonomi \\
\hline esenjangan ekonomi & meningkatkan \\
\hline eluarga secara & untuk membeli pangan \\
\hline ignifikan sangat terkait & dengan kualitas yang \\
\hline engan kekurangan gizi & lebih baik, keluarga \\
\hline $\begin{array}{l}\text { zronis pada anak-anak, } \\
\text { elain itu juga akses }\end{array}$ & $\begin{array}{l}\text { dengan faktor ekonomi } \\
\text { yang memadai akan }\end{array}$ \\
\hline rhadap pelayanan & memiliki kemampuan \\
\hline esehatan sangat sulit. & untuk menyediakan \\
\hline eluarga yang berstatus & semua kebutuhan baik \\
\hline ssial ekonomi yang & maupun \\
\hline endah atau miskin & sekunder anak. \\
\hline Imumnya mengalami & Keluarga dengan faktor \\
\hline lasalah gizi kurang & ekonomi yang baik juga \\
\hline (stunting) sedangkan & memiliki \\
\hline keluarga yang berstatus & pelayanan kesehatan \\
\hline osial ekonomi tinggi & yang lebih baik. Anak \\
\hline apat menunjang & pada keluarga faktor \\
\hline mbuh kembang & ekonomi rendah \\
\hline $\begin{array}{l}\text { aknya karena orang } \\
\text { menyedikan semua }\end{array}$ & cenderung \\
\hline
\end{tabular}


Zainal Munir: Stunting Balita

$\begin{array}{lr}\text { makanan dalam segi } \\ \text { kuantitas, kualitas, } \\ \text { serta variasi } & \text { yang } \\ \text { kurang dan akan } \\ \text { mengakibatkan } & \text { anak } \\ \text { stunting } & \end{array}$

\section{Daftar Pustaka}

alfarisi, R., Nurmalasari, Y., \& Nabila, S. (2019). Status Gizi Ibu Hamil Dapat Menyebabkan Kejadian Stunting Pada Balita. 5(3), 271-278.

Apriluana, G. (2018). Analisis Faktor-Faktor Risiko Terhadap Kejadian Stunting Pada Balita ( O59 Bulan ) Di Negara Berkembang Dan Asia Tenggara. 247-256.

Aramico, B., Sudargo, T., \& Susilo, J. (2013). Dengan Stunting Pada Siswa Sekolah Dasar Di Kecamatan Lut Tawar, Kabupaten Aceh Tengah. 1(3), 121-130.

Cahyono, Tri, 2018, Statistika Terapan Dan Indikator Kesehatan, Yogyakarta, Penerbit Deepublish

Darmawan. (2013). Metode Penelitian Kuantitatif. Bandung: Remaja Rosdakarya.

Diana Mardhiah, Ikeu Ekayanti, And Budi
Setiawan, 2019, The Relationship Between Mother's Nutritional Knowledge Towards Fruits Vegetables Consumption And Nutritional Status Of Pre School Children Kindergarten Salman Jakarta: International Meeting Ofpublic Health And The 1st Young Scholar Symposium On Public Health, Hal ,47-52.

Ernawati, D., \& Arini, D. (2020). Profil Balita Stunting Di Wilayah Kerja Puskesmas Kenjeran Kota Surabaya. Vol.6, 1-10.

Ernawati, F., Rosmalina, Y., \& Permanasari, $\mathrm{Y}$. (2016). Pengaruh Asupan Protein Ibu Hamil Dan Panjang Badan Bayi Lahir Terhadap Kejadian Stunting Pada Anak Usia 12 Bulan Di Kabupaten Bogor (Effect Of The Pregnant Women's Protein Intake And Their Baby Length At Birth To The Incidence Of Stunting Among Children. 1(36), 1-11. 
Ekayanthi, N. W. D., \&

Suryani, P. (2018).

Edukasi Gizi pada Ibu

Hamil Mencegah

Stunting pada Kelas Ibu

Hamil. 10, 312-319.

F, C. A., Perdana, A. A., \&

Humairoh. (2019).

Faktor Kejadian Stunting

Balita Berusia 6-23

Bulan Di Provinsi

Lampung. 7, 127-134.

Fedriansyah,

D.,

Paramashanti, B. A., \&

Paratmanitya, Y. (2020).

Faktor Sosial Ekonomi

Dan Stunting Pada Anak

Usia 6-23 Bulan. 27, 22 29.

Fitri Handayani, Albiner

Siagian, Evawany Y

Aritonang, 2017, Mother '

$S$ Education $A \quad S \quad A$

Determinant Of Stunting

Among Children Of Age

24 To 59 Months In North

Sumatera Province of

Indonesia: Journal of

Humanities And Social

Science, Vol, 22, No.6 , Juni, Hal, 58-64

Francesco Burchi, 2010, Economics And Human Biology Child Nutrition In Mozambique In 2003 : The Role Of Mother ' $S$
Schooling And Nutrition

Knowledge: Economics

And Human Biology,

Vol, 8, No.3, Hal ,331345

Fitrah, M., \& Luthfiya. (2017). Metodologi Penelitian (Pertama; Ruslan \& M. M. Effendi, Eds.). Jawa Barat: Cv Jejak.

Fitri, L. (2018). hubungan bblr dan asi ekslusif dengan kejadian stunting di puskesmas lima puluh pekanbaru. 3(1), 131137.

Fadhilah, siti nadiah nurul, Ningtyas, farida wahyu, \& Sulijstyani, S. (2019). tinggi badan orang tua, pola asuh dan kejaadian diare sebagai faktor resiko kejadian stunting pada balita di kabupaten bondowoso. 8(2), 140151.

https://doi.org/10.30644/ rik.v8i2.237

Grijns, M., Hari, H., Iranto, S., \& Saptandari, P. (2018). Menikah Muda Di Indonesia Suara, Hukum, Dan Praktik (Pertama; M. Grijns, H. Hari, S. Iranto, \& P. Saptandari, Eds.). Jakarta: Yayasan Pustaka Obor Indonesia. 
Handayani, T., Adriana, \& Nurfianti, A. (2017). Hubungan Antara Pola Asuh Orang Tua Terhadap Status Gizi Balita Di Upk Puskesmas Siantan Hulu. 1-10.

Ibrhahim, I. A., \& Faramita, R. (2015). Al - Sihah: Public Health Science Journal Hubungan Faktor Sosial Ekonomi Keluarga Dengan Kejadian Stunting Anak Usia 24 - 59 Bulan Di Wilayah Kerja Puskesmas Barombong Kota Makassar Tahun 2014. 7, 63-75.

Izah, N., Zulfiana, E., \&

Rahmanindar, N. (2020).

Analisis Sebaran Dan

Determinan Stunting

Pada Balita

Berdasarkan Pola Asuh

(Status Imunisasi Dan

Pemberian Asi

Eksklusif). 11(1), 27-32.

Khatimah, H., Abbas, H. H., Mahmud, N. U., \& Sididi, M. (2020). Karakteristik Kejadian Stunting Di Wilayah Kecamatan Mariso Kota Makassar. 01(02), 141147.

Khoirun Ni'mah, Siti Rahayu
Nadhiroh, 2015, Faktor Yang Berhubungan Dengan Kejadian Stunting Pda Balita : Vol . 10. No . 1 (Januari), 1319

Kullu, venny marisai, Yasnani, \& Lestari, H. (2019). faktor-faktor yang berhubungan dengan kejadian stunting pada balita usia 24-59 bulan di desa wawatu kecamatan maroma utara kabupaten konawe selatan tahun 2017. VI(1), 28-37.

Kawulusan, M., Walalangi, R.

G. M., Sineke, J., \& Mokodompit, R. C. (2019). Pola Asuh Dan Pendapatan Keluarga Dengan Kejadian Stunting Pada Anak Usia 2-5 Tahun Di Wilayah Kerja Puskesmas Bohabak. 11(2), 88-95.

Lapau, B. (2013). Metode Penelitian Kesehatan (2nd Ed.). Jakarta: Yayasan Pustaka Obor Indonesia.

Maharani, I., Mustofa, Linda Andri, \& Asiyah, S. (2018). Risk Factors Of Stunting Events In Age 25 Years. 9(2). 
M.C.Widjaja, 2011, Mengatasi Diare Dan Keracunan Pada Balita, Jakarta, Cv.Andi Offset (Penerbit Andi,Anggota Ikapi)

Maywita, E. (2015). Faktor Risiko Penyebab Terjadinya Stunting Pada Balita Umur 12-59 Bulan Di Kelurahan Kampung Baru Kec . Lubuk Begalung Tahun 2015. 3(1), 56-65.

Mugianti, S., Anam, A. K., \& Najah, Zian Lukluin. (2018). Faktor Penyebab Anak Stunting Usia 25-60 Bulan Di Kecamatan Sukorejo Kota Blitar 1. 268-278.

Https://Doi.Org/10.2669

9/Jnk.V5i3.Art.P268

Maryati Dewi, Mimin Aminah, 2016, Pengaruh Edukasi Gizi Terhadap Feeding Practice Ibu Balita Stunting Usia 6-24 Bulan : Indonesian Journal Of Human Nutrition, Vol. 3, No. 1 (Juni), 1-8.

Mitravinda S. Savanur, Mrinalini Purandare And Padmini S. Ghugre, 2015, Influence Of Birth Weight And Stunting On Selected
Cognitive Functions of Young Children In Low Socioeconomic Areas of Mumbai City : Journal Of Psychosocial Research Vol, 10, N0,2

Melinda Restu Pertiwi, Pudji Lestari, Elida Ulfiana, 2019, Relationship Between Parenting Style And Perceived Information Sources With Stunting Among Children: International Journal Of Nursing And Health Services, Vol.2, No. 4, Hal, 273-279.

Marini, Risna Galuh Septa, Widyastuti, N., \& Purwanti, R. (2019). Hubungan Pengetahuan Dan Sikap Responsive Feeding Dengan Kejadian Stunting Pada Baduta Usia 6-24 Bulan Di Wilayah Kerja Puskesmas Bandarharjo, Semarang. 8(2), 10-20. Https://Doi.Org/10.3064 4/Rik.V8i2.237

Miko, Agus Hendra A.

Rahmad Dan Ampera. (2017). Kajian Stunting Pada Anak Balita Berdasarkan Pola Asuh Dan Pendapatan 
Zainal Munir: Stunting Balita

Keluarga Di Kota Banda Aceh Study Of Stunting Among Children Under Five By Parenting And Family Income In Banda Aceh.

Natoatmodjo.

Metodelogi Penelitian

Kesehatan. Jakarta:

Rineka Cipta.

Ni'mah, K., \& Nadhiroh, S. R. (2015). Faktor Yang Berhubungan Dengan Kejadian Stunting Balita. Media Gizi Indonesia, 10(1), 13-19.

Noordiati. (2018). Asuhan Kebidanan Neonatus, Bayi, Balita, Dan Anak Pra Sekolah (1st Ed.). Malang: Penerbit Wineka Media.

Nurdin, I., \& Hartati, S. (2019). Metodologi

Penelitian Sosial (1st Ed.; Lutfiah, Ed.). Surabaya: Penerbit Media Sahabat Cendika. Nursalam. (2008). Konsep Dan Penerapan Metodologi Penelitian Ilmu Keperawatan (2nd Ed.; T. E. S. Medika, Ed.). Jakarta: Salemba Medika.

Nursalam. (2014). Metodelogi Penelitian Ilmu
Keperawatan (3rd Ed.). Jakarta:

Salemba Medika.

Nursalam. (2015). Metodologi Penelitian Ilmu Keperawatan (4th Ed.; A. Suslia, Ed.). Jakarta Selatan: Penerbit Salemba Medika.

Nursalam. (2017). Metodelogi

Peneitian Ilu

Keperawatan. Jakarta

Selatan: Salemba

Medika.

Ni'mah, K., \& Nadhiroh, S. R. (2015). Faktor Yang Berhubungan Dengan Kejadian Stunting Balita. Media Gizi Indonesia, 10(1), 13-19.

Noviana, U., \& Ekawati, H. (2018). Analisis Faktor Berat Badan Lahir, Status Ekonomi Sosial, Tinggi Badan Ibu Dan Pola Asuh Makan Dengan Kejadian Stunting Ulva. (2010), 31-45.

Ninna Rohmawati, Ruli Bahyu Antika, 2017, Risk Factors Stunting Incidence In Children Aged 6-36 Months In Jember Regency, November.

Oktarina, Z., \& Sudiarti, T. 
(2013). Faktor Risiko Stunting Pada Balita (2459 Bulan) Di Sumatra. 8(November), 175-180.

P, B. A., Angraini, W., \& Yanuarti, R. (2015).

Peningkatan

Pemahaman Siswa Smkn 3 Seluma Tentang Dampak Pernikahan Dini Dan Sex Bebas Sebagai Upaya Penurunan Angka Kejadian Kehamilan Di Luar Nikah.

Puspitaningrum, E. M. (2018). Hubungan Status Gizi Ibu Hamil Dengan Kejadian Berat Badan Lahir Rendah (Bblr) Di Rsia Annisa Kota Jambi Tahun 2018. 7(2), 1-7.

Ramayulis, R., Kresnawan, T., Iwaningsih, S., \& Rochani, Nur' Aini Susilo. (2018). Stop Stunting Dengan Konseling Gizi (I). Jakarta: Penebar Plus' (Penerbar Swadaya Group).

Riyadi, A. L. S. (2016). Ilmu Kesehatan Masyarakat (1st Ed.; Y. Sincihu, Steven, \& C. J. Dewi, Eds.). Yogyakarta: Cv.Andi Offset (Penerbit
Andi,Anggota Ikapi). Rahayu, A., \& Khairiyati, L. (2017). Risiko Pendidikan Ibu Terhadap Kejadan Stunting Pada Anak 6-23 Bulan (Maternal Education As Risk Factor Stunting Of Child 6-23 Months-Old). $37(\mathrm{Ci})$, 129-136. Retrieved From Nindya.Fitria@Gmail.Co $\mathrm{m}$

Rahmawati, A., Nurmawati, T., Sari, L. P., \& Kunci, K. (2019). Faktor Yang Berhubungan Dengan Pengetahuan Orangtua Tentang Stunting Pada Balita. 389-395. Https://Doi.Org/10.2669 9/Jnk.V6i3.Art.P389-395 Rita, W., Anita, B., Hidayah, N., Podesta, F., Ardiansyah, S., Subeqi, A. T., ... Riastuti, F. (2019). Hubungan pola asuh dengan kejadian stunting (rekomendasi pengendaliannya di Kabupaten Lebong). 8(2), 140-151.

Saefudin, W. (2019). Mengembalikan Fungsi Keluarga (I. Sungai \& K. Raya, Eds.). Kalimantan Barat. 
Sani, F. (2017). Metodologi Penelitian Farmasi Komonitas Dan Eksperimental (2nd Ed.). Yogyakarta: Penerbit Deepublish (Group Penerbit $\quad \mathrm{Cv} \quad$ Budi Utama).

Septikasari, M. (2018). Status Gizi Anak Dan Faktor Yang Mempengaruhi (1st Ed.; S. Amaliya, Ed.). Yogyakarta: Uny Press.

Setyosari, P. (2013). Metode Penelitian Pendidikan \& Perkembangan (4th Ed.; Tambra, Ed.). Jakarta: Prenadamedia Group.

Soetjiningsih. (1995). Tumbuh Kembang Anak (1st Ed.; D. Prof.Dr.Ig.N.Gde Ranuh, Ed.). Jakarta: Penerbit Buku

Kedokteran Egc.

Sugiono. (2010). Statistika Untuk Penelitian. Bandung: Alfabeta.

Suhaimi, A. (2019). Pangan,Gizi, Dan Kesehatan (Pertama; I. H. A. Saihani \& M. . Ruam Van Ronyensyah, Sp., Eds.). Yogyakarta: Grup Penerbit Cv Budi Utama.

Sari, R., Sulistianingsih, A., Pringsewu, S. M., \&
Apri, R. (2017). Faktor Determinan Yang Berhubungan Dengan Kejadian Stunting Pada Balita Di Kabupaten Pesawaran Lampung. 2(2).

Sukmawati, Hendrayati, Chaerunnimah, \& Nurhumaira. (2018). Status Gizi Ibu Saat Hamil, Berat Badan Lahir Bayi Dengan Stunting Pada Balita. 25. Sutarto, Mayasari, D., \& Indriyani, R. (2018). Stunting , Faktor Resiko dan Pencegahannya. 5, 540-545.

Sheila ,C.Vir, 2016, Improving women' $s$ nutrition imperative for rapid reduction of childhood stunting in South Asia : coupling of nutrition specific interventions with nutrition sensitive measures essential: Women's nutrition and child stunting in South Asia , vol, 12.

Sagirul Islam Majumder, Hedaytul Islam et al, 2017, Assessment of Nutritional Status Using 
Anthropometric Methods : A Study of Rural and Urban Primary Children in Coastal Belt of Bangladesh: science publishing group, vol. 2,no,5 hal 54-59.

Wa Ode Sri, Andriani, Farit Rezal, WD,ST.Nurzal Maariah, 2017: perbedaan penegetahuan pengetahuan, sikap,dan motivasi ibu sesudah di berikan program mother smart grounding (msg) dalam pencengahan stunting di wilayah kerja puskesmas puuwatu kota kendari tahun 2017 : jurnal ilmiah mahasiswa kesehatan masyarakat, Vol. 2, no.6 (mei), 1-9. Aramico, B., Sudargo, T., \& Susilo, J. (2013). dengan stunting pada siswa sekolah dasar di Kecamatan Lut Tawar, Kabupaten Aceh Tengah. 1(3), 121-130.

Worke Gete Alemayehu, 2018, Effect of Maternal Education , Early Marriage and Prenatal Care on Child Undernutrition in Ethiopia: American
Journal of Public Health

Research, vol,6, no,3

Widiyanti, H., Irianto, \&

Darawati, M. (2020).

Hubungan Pola Asuh

Dan Pola Pemberian Mp

- Asi Pada Bayi

Kekurangan Energi

Protein. 11, 61-68.

Yuliana, W., \& Hakim, B. N.

(2019). darurat stuntingdengan

melibatkan keluarga

(pertama). sulawesi

selatan: yayasan ahmar cendekia indonesia.

Yusuf, A. M. (2014). Metode Penelitian

Kuantitatif,Kualitatif \& Penelitian Gabungan (1st ed.; I. Fahmi, ed.). jakarta: PT. Fajar Interpratama Mandiri.

Yudianti, R. H. S. (2016). Pola Asuh Dengan Kejadian Stunting Pada Balita Di Kabupaten Polewali Mandar. 2, 21-25.

Zilda oktarina, Trini Sudiarti, 2013, Faktor Resiko Stunting pada balita (2459 bulan) di sumatera : Vol, 8, Nomor. 3 (November), 175-180. Zottarelli, L.k. Sunil, T.S. Rajaram, S. 2007, 
Influence of parental and socioeconomic factoron stunting in childern under 5 years in Egypt: La Revue de Sante de la maditerranee orientale, vol, 13 , no. 6 